\title{
Structural and Attitudinal Barriers in Education and Training: The Lived Experiences of Disabled Women
}

Aizan Sofia Amin, Arena Che Kasim, Khairul Farhah Khairuddin, Rafidah Mohamad Cusairi \& Mohd Iqbal Haqim Mohd Nor

To Link this Article: http://dx.doi.org/10.6007/IJARBSS/v11-i3/8915 DOI:10.6007/IJARBSS/v11-i3/8915

Received: 09 January 2021, Revised: 04 February 2021, Accepted: 25 February 2021

Published Online: 10 March 2021

In-Text Citation: (Amin et al., 2021)

To Cite this Article: Amin, A. S., Kasim, A. C., Khairuddin, K. F., Cusairi, R. M., \& Nor, M. I. H. M. (2021). Structural and Attitudinal Barriers in Education and Training: The Lived Experiences of Disabled Women. International Journal of Academic Research in Business and Social Sciences, 11(3), 26-35.

Copyright: (c) 2021 The Author(s)

Published by Human Resource Management Academic Research Society (www.hrmars.com) This article is published under the Creative Commons Attribution (CC BY 4.0) license. Anyone may reproduce, distribute, translate and create derivative works of this article (for both commercial and non-commercial purposes), subject to full attribution to the original publication and authors. The full terms of this license may be seen at: http://creativecommons.org/licences/by/4.0/legalcode

Vol. 11, No. 3, 2021, Pg. 26 - 35

Full Terms \& Conditions of access and use can be found at http://hrmars.com/index.php/pages/detail/publication-ethics 


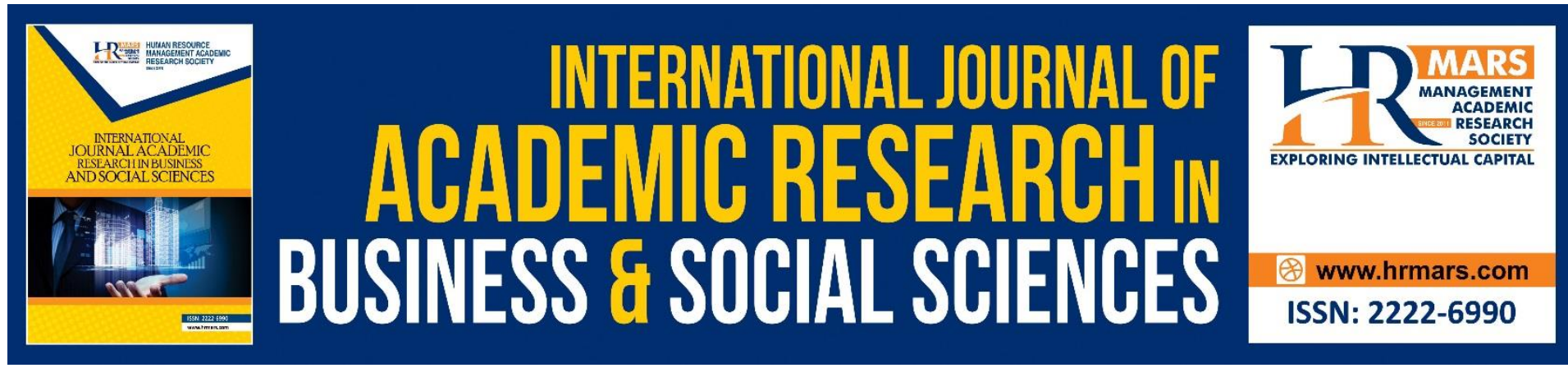

\title{
Structural and Attitudinal Barriers in Education and Training: The Lived Experiences of Disabled Women
}

\author{
Aizan Sofia Amin ${ }^{1}$, Arena Che Kasim¹, Khairul Farhah \\ Khairuddin², Rafidah Mohamad Cusairi ${ }^{3}$ \& Mohd lqbal Haqim \\ Mohd Nor ${ }^{4}$ \\ Faculty of Social Sciences and Humanities, Universiti Kebangsaan Malaysia ${ }^{1}$, Faculty of \\ Education, Universiti Kebangsaan Malaysia ${ }^{2}$, School of Languages, Civilisation \& Philosophy, \\ Universiti Utara Malaysia ${ }^{3}$, School of Social Sciences, Universiti Sains Malaysia ${ }^{4}$ \\ Email: arena@ukm.edu.my
}

\begin{abstract}
The Malaysian government has developed significant disability provision, policies and legislations since the period of colonialism, but disabled people still encounter major barriers in education and training. Although disability is argued to have some relation to gender and culture, significant research involving Malaysian disabled women in terms of education and training is very limited. This paper therefore sets to explore the lived experiences of Malaysian disabled women in education and training. This study used a full qualitative research approach in which the data was collected from in-depth interviews with 33 Malaysian women with physical (mobility) impairment. 17 Malays, 8 Chinese and 8 Indian women were interviewed twice in Peninsular Malaysia within the period of six months. The majority of women came from low-income and rural families. Findings suggested that structural and attitudinal barriers were found to be the main barriers for many women to access education and training. Hence, their situation was aggravated by complex interactions between individual, familial, sociocultural and gender factors.
\end{abstract}

Keywords: Barriers, Education, Training, Disabled Women, Malaysia

\section{Introduction}

Conventions of the Rights of People with Disabilities (CRPD) has listed education as one of the main rights of people with disabilities or disabilities (United Nations 2006). The convention states that the disabled have the right to obtain education in an environment that is inclusive and accessible to persons with disabilities. The convention also states that any form of discrimination in obtaining the education have to be addressed (United Nations, 2006).

Furthermore, the World Health Organisation (WHO) and the World Bank in their World Report on Disability estimate that over one billion or 15 percent of the world population have some form of disability (WHO, 2011). From this global estimate, the 
prevalence of disability is more common amongst the poor and higher in lower income/developing countries where 80 percent of disabled people live (WHO, 2011). While the incidence of disability is higher in developing countries, empirical research involving disabled people from this part of the world is scarce (Grech, 2009; WHO, 2011; Shakespeare, 2012). Globally disabled people experience greater socioeconomic disadvantages:

Across the world, people with disabilities have poorer health outcomes, lower education achievements, less economic participation and higher rates of poverty than people without disabilities. This is partly because people with disabilities experience barriers in accessing services that many of us have long taken for granted, including health, education, employment, and transport as well as information. These difficulties are exacerbated in less advantaged communities (Chan \& Zoellick, 2011: xi).

More importantly disability is found to be more widespread amongst women than men (WHO, 2011). The Global Burden Disease and the World Health Survey both estimate that females have a higher percentage of disability than males (WHO, 2011). This indicates that the developing countries such as Malaysia may observe a higher percentage of disability amongst women than men. However, research involving Malaysian disabled women is very limited and little is known of how they experience their lives. This paper therefore sets to explore how Malaysian women with physical impairment experience their opportunity for education and training. Even though the government provides formal educational programmes for disabled students especially those with physical impairments, they still face significant barriers in gaining access to education The main issues are in terms of infrastructure and the accessibility of schools. The government's report indicates that 82.9 percent of primary schools and 58.5 percent of secondary schools are in rural areas throughout the country (NGO Shadow Report Group, 2005). Many schools in rural areas in the state of Sabah were reported to have poor infrastructure and facilities, as well as a lack of qualified teachers.

Moreover, many secondary schools are situated far from students' residence; they are concentrated in urban areas and require students to leave home for schooling. This may hinder students from poor families from gaining proper education due to transportation constraints, especially for those students with mobility impairment. For example, many disabled children in Malaysia, especially those in rural areas and those who have mobility impairments, are unable to attend schools due to environmental barriers such as inaccessible school buildings and transportation problems (Kuno, 2007; Ong et al., 2002; NGO Shadow Report Group, 2005). Students in higher learning institutions also face environmental and attitudinal barriers in their universities (Hasnah et al., 2009). These prove that disabled people in Malaysia are facing multiple barriers to education in their quest for equal opportunities to obtain formal education at all levels of primary, secondary and tertiary education.

Barriers to education for disabled young women are also common in other countries such as Thailand. Ito (2010) found that young disabled girls with hearing impairments and intellectual disabilities are subjected to inadequate education opportunities and, as such, are easily being exploited. Disabled women in the rural areas of South Sulawesi Indonesia have also been stigmatised, resulting in them receiving minimal education or training (Schuller et 
al., 2010). In India, disabled women are also subjected to unequal opportunities for proper education. For instance, in the Raichur district of the Karnataka State of India, the literacy rate of disabled women was only 7 percent, as compared to the general literacy rate of the state which was reported to be about 46 percent. These examples therefore clearly show that disabled women in many countries have unequal opportunities for education (Rao, 2010). These findings show that in many countries and different socio-cultural contexts, gender issues still have profound impacts that restrict women's opportunities for equal education. This study therefore sets out to provide empirical evidence regarding barriers to education and training experience by Malaysian women with physical impairment.

\section{Methods}

This full qualitative research used narrative approach (Creswell, 2007; Jovchelovitch \& Bauer 2000) that explores the lived experiences of the research participants. Thestudy was conducted in three states of Peninsular Malaysia: Kuala Lumpur, Selangor and Negeri Sembilan. However, the majority of informants formerly lived in other states in Malaysia; all over the country including states in Borneo such as Sabah and Sarawak. The data of this study was collected from in-depth interviews with 33 Malaysian women with physical (mobility) impairment. Over a period of 6 months, 17 Malays, 8 Chinese and 8 Indian women were interviewed twice. The majority of participants were interviewed twice in 6 months to understand their lives in relation to employment experiences. The time interval between the first and second interview was 3 to 6 months. The in-depth interviews were conducted twice to give space to the research participants to share experiences that are more sensitive in the second interview. They were interviewed in a conducive environment such as at the nongovernmental organization premises and the research participants' home.

The participants were recruited through three different strategies - recruitment via: non-governmental organisations (NGOs) for disabled people (six NGOs for disabled people in Malaysia), disabled friends' networking, and snowballing (Lewis-Beck et al. 2004). The research participants had different types of physical (mobility) impairment such as spinal cord injury, polio, spinal muscular atrophy, muscular dystrophy, marfan syndrome, systemic lupus erythematosus, traumatic brain injury, gestational diabetes mellitus, osteosarcoma, spina bifida, teratoma, dysmelia, leg amputation and leg injury.

The research participants' age ranged from 21 to 57 years old. The majority of women interviewed came from low-income and rural families and thus many of them had limited access to basic living needs, such as healthcare, transportation, education and training, as well as employment. The data gathered from the in-depth interviews were transcribed and then organised in a computer software - QSR NVivo 9. The data were then analysed by using thematic analysis (Bazeley, 2007; Creswell 2007; Gibbs 2011) to examine their lived experiences pertaining to education and training opportunites.

\section{Results and Discussions \\ Educational Background}

This section examines the educational background of the participants. Of the 33 women, the majority attended formal schooling provided by the state, with 14 of them completing secondary (high) school and sitting the Malaysian Certificate of Education (Sijil Pelajaran Malaysia - SPM). Eight of them sat the Lower Secondary Assessment (Penilaian Menengah 
Rendah - PMR) but did not complete secondary school; while two of them completed primary school and sat the Primary School Evaluation Test (Ujian Penilaian Sekolah Rendah - UPSR), yet they did not proceed to secondary school. Two women never attended formal schooling; they learnt to read and write informally at home. However only seven women managed to complete secondary school and progressed to higher education to study a diploma, degree, masters or Doctor of Philosophy (PhD).

This contradicts with the general pattern of educational attainment amongst female population in Malaysia. According to the 2010 Census, almost 68.9 percent females aged 15 years and above obtained a tertiary education; as compared to males who were only about 66.8 percent (Department of Statistics Malaysia, 2011). It indicates that the majority of participants achieved a lower academic level than the rest of the Malaysian females' population.

Furthermore, it has also been discussed that the low enrolment of disabled female in education could also be due to the negative perceptions towards woman education as well as the "overprotective" attitudes of parents (Possi 2018). This shows that gender issues within disability exists and need to be addressed. Therefore, this paper will reveal how many of the women interviewed encountered significant obstacles in their education and training experiences in terms of structural barriers, attitudinal barriers, and limited opportunities for training.

\section{Structural Barriers}

For many of the women interviewed, especially those in wheelchairs, structural barriers at school became a major obstacle to their continuing within education. For example, Fatin ${ }^{1}$, a wheelchair user, explained that she had to quit school because her school failed to provide an accessible classroom for her:

After I recovered from the accident, I wanted to continue my studies at secondary school. Unfortunately, I couldn't register to form 1 [equal to Year 8 in British secondary education] because all the classrooms were located on the upper floor. So, I couldn't take my PMR at school and I took it as a private candidate [...] After PMR I didn't take SPM because it was hard to study alone at home.

Similarly, Lijuan also experienced similar environmental barriers at school. She not only encountered inaccessible school buildings but also was unable to find suitable transport to the school due to her impairment and poverty:

I didn't go to school after standard 6. There were a few steps in my school which I couldn't take. Although the school's buildings were all single storey, there were a few steps in the buildings. So I couldn't go and my mum also didn't have time as she had to look after my siblings. I also couldn't get onto the school bus because it had a few steps at the door. It was really difficult [...] I

\footnotetext{
${ }^{1}$ All the participants' names were referred to using pseudonyms to protect their identity and to ensure anonymity.
} 
felt upset that I couldn't go to school lor. I liked going to school, it was fun, but I couldn't do it.

Lijuan's family could not provide a car or assistance for her getting to her school because they were poor and apparently neither the state nor school provided adequate support for her. The inaccessibility of Fatin and Lijuan's schools had prevented them from having an equal opportunity to gain an education and as a result both had to quit school earlier than they wished. This lack of education clearly had long term consequences, leaving them 'less likely to become employed, and are more likely to remain poor' (Shakespeare, 2012).

Others, such as Cuifen, were able to continue schooling but had to compromise to do so. For example, she had to overcome her embarrassment at being forced to use a male toilet just because she used a wheelchair at school:

I felt really upset that I could become like this [...] the female toilet was located on the upper floor and the male toilet on the ground floor. So I had to go to the male toilet. I felt really embarrassed using the male toilet because there were male students going there. I was so ashamed but I didn't have a choice. I had to bear with it for the two years I studied there.

The failure of the school authority to provide an accessible female toilet for Cuifen significantly impacted on her psycho-emotional wellbeing as a woman despite her physical needs being met.

In general as examined from the participnts' point of view, the structural barriers such as lack of accessibility towards building and facilities will not only impact on the psychoemotional well-being of disabled women but also it causes them to experience economical outcomes.. This further suggests that the socio-cultural ideologies on disabilities especially in Asian countries is clearly impacting the opportunities for equal education of disabled people (Tiwari, Das and Sharma, 2015).

\section{Attitudinal Barriers}

As well as structural barriers, many of the women had encountered disabling attitudes from their own family, school authorities and friends in realising their right for education. Yana for example, who came from a rural area, never had the chance to go to school because her parents never wanted to expose her to the public:

Yana: I didn't go to school. I never attended school and only got home tuition [her parents taught her at home]. My family didn't send me to school.

Researcher: What made your family not send you to school?

Yana: How I want to say, they didn't have a car at that time. And then, they didn't really bother about it. They thought it would be difficult for me to go to the toilet at school. My family was having some problems. I have some family problems. 
Researcher: Family problems? If you don't mind, could you tell me a little bit about it?

Yana: I don't know, my family used to be like that. Like for example, when I went out with them to go to the supermarket, they seemed ashamed of me. Yes, they take me out but I can feel that they don't really feel happy. They seemed to avoid pushing my wheelchair.

Researcher: Ehem... They? Who are they?

Yana: My mum and dad.

Yana felt that her parents did not send her to school because they were ashamed of her impairments and this made her feel they did not accept her. As a result of this abandonment, she developed low self-esteem which was amplified by the fact that she was not included in the education and in other normal family activities.

For many of the other women the disabling attitudes of their school authorities became a major obstacle to them attaining education. For example, Dilah described how her aspiration to excel in education was 'ruined' by her school authorities:

After I recovered from amputation surgery, I wanted to continue my studies to form four. So I applied to the local school but they refused my application. They refused because they said that I was so far behind in my studies. Before I fell sick, I had already informed them that I couldn't go to school temporarily. Then, when I wanted to continue my studies after recovery they didn't allow me [...] I felt so frustrated and upset. I'm not praising myself but I had been a good student ever since primary school. I always got good grades in my class. So I thought I could excel in my studies but unfortunately I can't.

Despite the disabling attitudes displayed by parents and school authorities, some of the women also had to deal with the negative attitudes exhibited by their friends at school. Cuifen, who lived in an urban area, described how she was not only discriminated against by her school authority but was also bullied by her school friends:

During school days, I was always being bullied by my friends until I wanted to quit school [...] Then I informed my mum that I didn't want to go to school. She asked me why I didn't want to go to school. I said lah there were students who beat me, they bullied me, and some of them put nails in my wheelchair tyre. So my dad was angry. He went to see the headmaster. Then he went to the Welfare Department and warned the headmaster that he had no right to dismiss me from the school. After the headmaster received the letter only then he allowed me to continue my studies. I felt very upset by such incidents as if I was like an unwanted student in the school.

This section has shown how the participants from both the urban and rural areas were prevented from getting formal education due to their impairment because of negative 
attitudes displayed by their parents, school authorities, and school friends. They not only experienced structural and attitudinal barriers in realising their right for proper education but also had problems getting adequate training as discussed next. The emergence of negative social attitudes alongside with inhospitable physical environment will result in systematic oppresion, exclusion and discrimination towards disabled people (Lang, 2001). Thus, it is vital that these attitudinal barriers to be addressed and eliminated.

\section{Limited Opportunities for Training}

More than 50 percent of the women interviewed attended vocational training for disabled people at least once in their lifetime; regardless of their educational background. 12 out of the 17 Malay informants received vocational training from at least one disabled person's institution, three out of the eight Chinese participants also attended a vocational training course at a disabled person's institution, and two out of the eight Indian women did the same. Most of them came from rural areas and low-income families and as such the vocational training provided by the state and the NGOs became one of the best options that they had.

Although many women underwent vocational training for disabled people, some of them discovered there were narrow prospects for gaining access to their desired training course. The vocational courses in the rehabilitation centre offered by the state (Department of Social Welfare) were very limited and gender based. For example, Yasmin who acquired her impairment at the age of 16 described how she had limited opportunities to choose a course that she liked:

I didn't take the SPM. I spent about two years in my room. Then, I heard from a radio station that there was a rehabilitation centre for disabled people in $X$ (a state in Malaysia). I applied and accepted. I was actually intending to take the SPM in the centre but unfortunately they only offered vocational courses like tailoring, repairing radios and TVs. So as a female, I could only choose tailoring to study, which I didn't like. So I didn't actually learn and just stayed there for like a year. Then after a year I came back home.

Yasmin decided to continue her education in the rehabilitation centre for disabled people after she acquired her impairment. In her case, the inaccessibility of the local mainstream school did not allow her to attend. At the same time, like many of the other women interviewed, she felt unable to continue schooling with non-disabled peers because she was afraid that they could not accept her disability. Therefore, her academic ambitions and aim of taking the most vital exam (SPM) in Malaysia was not realised - neither in the mainstream school nor in the rehabilitation centre for disabled people. Thus, she was denied her right for proper education and training. Similarly, Intan was also not given a choice when selecting her vocational course:

I studied there [a rehabilitation centre for disabled people] in 1985. I learnt tailoring. At that time we had three classes for tailoring and all of them were full. The majority were female students. I was not really interested in tailoring actually. That was the only available course for girls. All girls went for the tailoring course and boys went for the one repairing radios, TVs and cars. So, I just learnt it as it was the only option I had. 
Whereas Nadia had to quit her vocational training programme because she was not fully allowed to study her desired course: instead she was assigned to tailoring:

I studied full time tailoring and part-time computing [IT course] there. It was a two year programme but I quit after 1 year and five months. I told the deputy director [of the vocational centre] that I wanted to study computing full time because I didn't like tailoring. However he didn't allow me to change my course and therefore I quit.

The vocational courses offered by the state were often based on traditional gender roles, and women were assigned to crafts, or feminine courses like tailoring; while men were enrolled on mechanical courses, such as repairing cars, televisions, and radios. Such gender bias in vocational training for disabled women may have impeded their full potential for employment or career development as discussed earlier. This suggests 'multiple discrimination' was practised against these women, making them feel at a greater disadvantage because not only were they trained for work which would result in low paid positions, but they were also restricted to only 'feminine work'. Thus, the ideal way to move forward is to facilitate and support the capacity building of disabled people through exchanging the information and and sharingexperiences in deciding which training programmes are suitable and which are best to be put into practice (Swedish International Development Agencies, 2014). By doing this, it is expected that disabled women in Malaysia can be empowered to fulfil their full potential in education and in employment.

\section{Conclusion}

This paper discusses how Malaysian women with physical impairment experience their opportunity for education and training. The findings revealed that many of the women had limited access to education and training due to structural and attitudinal barriers as well as limited opportunities for training. Hence, their situation was exacerbated by complex interactions between individual, familial, sociocultural and gender factors (Aizan et al., 2020). For a developing country like Malaysia it was important to observe how a lack of accessibility both in rural and urban areas, and poverty, had significantly impacted disabled women's wellbeing in terms of their educational and training attainments. At the same time, lack of support from the welfare state and societal disabling attitudes towards these women also played important roles in excluding them from wider social and economic activities.

The structural and attitudinal barriers that hindered equal opportunity for education and training systematically prevented their prospects for employment, leading them to poverty. Limited opportunities for training also barred many women from having wider prospects in employment and restricted their full potential as active agents in society. Disabled females are fare less to be in education due to the double discrimination as resulted fromgender and disability issues (Rousso, 2015). Therefore, the substantial support and assistance from the state multi-agencies such as the Department of Social Welfare, Ministry of Education and Ministry of Human Resource as well as the NGOs are important for disabled females in Malaysia to overcome these barriers in education and training that has been discussed in the paper. In conclusion, the state multi-agencies in Malaysia can work together proactively in supporting the needs and ability of students with physical impairments at schools, higher learning institutions and vocational training centres for disabled people. 


\section{References}

Aizan, S. A., Najwa Afiqa, R., \& Md. Akhir, N. (2020). The cultural representation of disabled women in Malaysia. International Journal of Psychosocial Rehabilitation, 24(04), 41404153.

Chan, M., and Zoellick, R. B. (2011). Preface. In: WHO. World report on disability. Geneva: World Health Organization, xi.

Department of Statistics Malaysia. (2011). Population distribution and basic demographic characteristic report 2010. http://www.statistics.gov.my/portal/index.php?option=com_content\&id=1215

Grech, S. (2009). Disability, poverty and development: Critical reflections on the majority world debate. Disability \& Society, 24(6), 771-784.

Hasnah T., Hanafi, M. Y., Mokhtar, M. T., \& Norasuzaini, S. (2009). Sokongan dan Halangan yang dihadapi Pelajar-Pelajar Kurang Upaya di Sebuah Institusi Pengajian Tinggi Di Malaysia. ASEAN Journal of Teaching and Learning in Higher Education, 1(2), 18-29.

Ito, N. (2010). Convention on the Rights of Persons with Disabilities and Perspectives of Development Assistance: A Case Study of Thai Disability Policy. Asia Pacific Disability Rehabilitation Journal, 21(1), 43-58.

Kuno, K. (2007). Does Community Based Rehabilitation Really Work? Community Based Rehabilitation (CBR) and Participation of Disabled People. ISM Research Monograph Series No. 5. Kuala Lumpur: Social Institute Malaysia.

Lang, R. (2001). The Development and Critique of the Social Model of Disability.

NGO Shadow Report Group. (2005). NGO Shadow Report on the Initial and Second Periodic Report of the Government of Malaysia: Reviewing the Government's Implementation of the Convention on the Elimination of All Forms of Discrimination against Women (CEDAW). Kuala Lumpur: NCWO and WAO.

Ong, L. C., Lim, Y. N., \& Sofiah, A. (2002). Malaysian children with Spina Bifida: relationship between functional outcome and level of lesion. Singapore Medical Journal, 43(1), $12-$ 17.

Possi, M. K. (2018). Gender and education of people with disabilities in Tanzania. Utafiti Journal, 3(2).

Rao, I. (2010). Equity to women with disabilities in India accessed 14 September 2011, from http://www.cbrnetworksouthasia.org.in/uncrpd_equity.php?id=16

Schuller, I. (2010). The way women experience disabilities and especially disabilities related to leprosy in rural areas in south Sulawesi, Indonesia. Asia Pacific Disability Rehabilitation Journal, 21(1), 60-70.

Tiwari, A., Das, A., \& Sharma, M. (2015). Inclusive education a "rhetoric" or "reality"? Teachers' perspectives and beliefs. Teaching and Teacher Education, 52, 128-136.

United Nations. (2006). The United Nations Convention on the Rights of Persons with Disabilities. doi:10.1145/2566968

WHO. (2011). World report on disability. Geneva: World Health Organization. 